\title{
Clustering on Web usage data using Approximations and Set Similarities
}

\author{
K.Santhisree \\ Associate professor \\ Department of Computer science \\ JNTU,Hyderabad (A.P) INDIA
}

\author{
Dr A.Damodaram \\ Prof \&Director of UGC \\ Academic Staff College \\ JNTU,Hyderabad (A.P), INDIA
}

\begin{abstract}
:
Web usage mining is the application of data mining techniques to web log data repositories. It is used in finding the user access patterns from web access log. User page visits are sequential in nature. In this paper we presented clustering web transactions based on the set similarity measures from web log data which identifies the behavior of the users page visits, order of occurrence of visits . Web data Clusters are formed using the Similarity Upper Approximations. We present the experimental results on MSNBC web navigation dataset which are sequential in nature. clustering in web usage mining is finding the groups which share common interests and behavior by analyzing the data collected in the web servers. This study contributes the topic clustering of web usage data and shows the interests and behaviors of the various user visits .
\end{abstract}

The full text of the article is not available in the cache. Kindly refer the IJCA digital library at www.ijcaonline.org for the complete article. In case, you face problems while downloading the full-text, please send a mail to editor at editor@ijcaonline.org 